\title{
LINGUISTIC AND PRAGMATIC PARAMETERS OF THE PHENOMENON OF PATRIOTISM IN THE FORMATION OF A NATIONAL BRAND (A CASE STUDY OF THE LANGUAGE OF CONTEMPORARY MEDIA)
}

\author{
Ushchapovska Iryna \\ Senior lecturer \\ ORCID ID 0000-0001-9746-5581 \\ Sumy State University \\ 2, Rymskoho-Korsakova St, Sumy, 40007, Ukraine \\ i.ushchapovska@gf.sumdu.edu.ua \\ Markova Olga \\ Candidate of Sciences in Philology \\ ORCID ID 0000-0002-9441-5973 \\ b111zzz000111@gmail.com
}

The message of national identity is delivered in different types of discourse - political, economic, the discourse of show business and sport, advertising, tourism discourse, and more. The article describes the way the linguistic and pragmatic parameters of the phenomenon of patriotism form messages of national identity in the newspaper discourse, since with the increasing globalization of the communicative space, the types of communication aimed at manifesting national identity, namely, national branding, gain special significance. Providing conditions for the development of a national brand of any country is extremely relevant in view of integration and civilization processes, social, economic and geopolitical situation, and mass media propaganda. Cultural symbols, which are mental-cognitive units focused on a certain idea of the country and represent the typical reality, a typical phenomenon or a characteristic feature of civil life, play an important role in messaging the national identity. A cultural symbol may be expressed by a keyword denoting a cultural-labeled concept, stereotype, or a precedent. The phenomenon of patriotism, which is formed upon the higher feelings, is the basic axiological dominance of society, although the modern rethinking of value associations has led to the formation of changes in the concept of patriotism: noticeable tangible adjustments have been made by historical and social conditions over time. Patriotism is based on the emotional aspect of the nation-state outlook. Linguistic and pragmatic aspects of the phenomenon of patriotism in English-language newspaper texts reveal informative, evaluative, and instructive functions. Being formed under the influence of traditions, life experience, the system of values of the country they create prerequisites for the attitude of a person to his compatriots, the country, and the whole world.

Keywords: national brand, national identity, the phenomenon of patriotism, the language of contemporary media, linguistic and pragmatic parameters.

\section{ЛІНГВОПРАГМАТИЧНІ ПАРАМЕТРИ ФЕНОМЕНУ «ПАТРІОТИЗМ» У ФОРМУВАННІ НАЦІОНАЛЬНОГО БРЕНДУ (НА ПРИКЛАДІ МОВИ СУЧАСНИХ АНГЛОМОВНИХ ЗМІ)}

\author{
Ущаповська Ірина \\ Старший викладач \\ ORCID ID 0000-0001-9746-5581 \\ Сумський державний університет, \\ вул. Римського-Корсакова, 2, м. Суми, 40007, Україна \\ i.ushchapovska@gf.sumdu.edu.ua
}

(C) Ushchapovska I., Markova O., 2020 


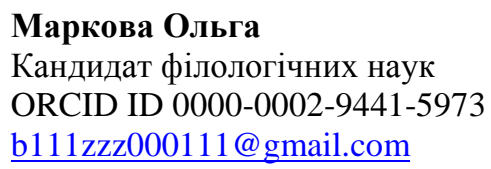

Повідомлення начіональної ідентичності відбувається у різних видах дискурсу політичному, економічному, дискурсі шоу-бізнесу та спорту, рекламному, дискурсі туризму тощз. У статті окреслено, як лінгвопрагматичні параметри феномену «патріотизм» формують повідомлення національної ідентичності у газетному дискурсі, оскільки зі зростанням глобалізації комунікативного простору особливого значення набувають ті види комунікації, щзо мають на меті вияв національної ідентичності, а саме: національний брендинг. Створення умов для розвитку національного бренду будь-якої краӥни є вкрай актуальне з огляду на інтеграџійні й загальноцивілізаційні процеси, соціально-економічну $і$ геополітичну ситуацію, масмедійну пропаганду. Важливу роль у повідомленні національної ідентичності відіграють культурні символи, щзо $\epsilon$ ментально-когнітивними одиницями, які фокусують у собі певне уявлення про краӥну і позначають типову для неї реалію, типове явище чи типову ознаку життя громадян. Культурний символ може бути виражений ключовим словом, щзо позначає культурно-маркований концепт, стереотипом або прецедентним феноменом. Феномен «патріотизм», формуючись на вищих почуттях, є базовою аксіологійною домінантою суспільства, хоча сучасне переосмислення иіннісних асоціаџій спричинило формування змін у понятті «патріотизм»: помітно відчутні корективи часом, історичними та соиіальними умовами. Патріотичність трунтується на емочійному аспекті національнодержавницького світогляду. Лінгвопрагматичні аспекти феномену «патріотизм» 6 газетних англомовних текстах виявляють інформативну, оиінну та настановну функиії, сформовані під впливом традицій, життєвого досвіду, системи иінностей краӥни, створюючи передумови ставлення людини до співвітчизників, краӥни, усього cвimy.

Ключові слова: національний брендинг, національна ідентичність, феномен «патріотизм», мова сучасних 3МI, лінгвопрагматичні параметри.

Introduction. With the increasing globalization of the communicative space, the types of communication aimed at conveying national identity, national branding being one of them, gain particular significance [1, p. 80]. Cultural symbols, which are mental-cognitive units focused on the idea of the country and mark the country's typical reality, a typical phenomenon or a typical feature of life, play an important role in the message of national identity. A cultural symbol may be expressed by a keyword denoting a cultural-labeled concept, stereotype, or a precedent [2, p. 392], which is the phenomenon of patriotism. Formed on higher feelings, it is the basic axiological dominant of society.

The modern rethinking of value associations has led to changes in the concept of patriotism: there are noticeable tangible adjustments to times, historical and social conditions, especially in the context of globalization when the national culture is replaced by the mass culture. Accordingly, the concept of the text as an object of the analysis gradually changed: the text is viewed together with the features of the context that determine its communicative, structural, semantic, and rhetorical features. Linguists distinguish four basic communicative (pragmatic) functions of the text: signifying, informative (influence on the intellectual sphere of the recipient through the description of things, phenomena, and events); evaluative (influence on the system of views, change of attitude of the addressee of the message to phenomena, objects, etc.); instructive (influence on the behavior of the recipient of the information) [3, p. 12].

The relevance of the research is determined by the special place of the phenomenon of patriotism in the linguistic worldview and its importance for the individual, as well as the linguistic community as a whole. Until now, the means of explicating patriotism in the 
English-language worldview still have to be considered, so the analysis of contemporary English-language newspaper discourse will contribute to a deeper understanding of the dominant values of society.

The message of national identity occurs in different types of discourse - political, economic, discourse of show business and sport, advertising, tourism discourse, etc. [1, p. 81]. In this paper, we explore the ways linguistic and pragmatic parameters of the phenomenon of patriotism shape messages of national identity in the newspaper discourse.

The founders of the concept of national branding are Ph. Kotler, S. Anholt, W. Olins, K. Dinnie, P. Van Ham, J. Hildreth. Such authors as G. Szondi, Y. Fan, N. Kaneva, and L. Fomenko further developed this concept; K. Bliznyuk, O. Markova, L. Pisarenko, O. Sklyarova, M. Yegorov, and others considered the phenomenon of patriotism in terms of linguistics.

The purpose of the article is to analyze the linguistic means of implementing the phenomenon of patriotism in the creation of a national brand used in the language of contemporary English-language media.

The subject of the research is the phenomenon of patriotism as an important element of national branding.

The subject of the research is linguistic mechanisms of constructing the phenomenon of patriotism, its characteristics (lexical and semantic), and pragmatic functioning in contemporary English-language media.

Materials of the study were sources of illustrative material (electronic versions of the Daily Mail, Morning Star, Mirror, The Telegraph, and Sunday Express).

The continuous sampling method of English-language newspaper texts in the period of 2008-2019 revealed 600 cases of use of the lexical item of "patriotism", as well as 100 cases of its indirect nomination.

Results of the research. National identity is a subjective relation, individual and collective, with the national community, a sense of belonging to it, its history, territory, culture, its political and economic interests [4, p. 11]. Therefore, national identity, as a special form of social identity, is created and reproduced, as well as being changed and destroyed in the discourse [5, p. 4].

The need to form a national brand and a favorable perception of the country in the international arena indicates the importance of scientific analysis of existing theoretical approaches to the interpretation of modern national branding strategies. National branding is a series of measures in the fields of exports, tourism, culture, domestic and foreign policy, and investment in developing and implementing the state brand building strategy aimed at improving the image of the country, perceived by the local population and foreigners and enabled by a variety of instruments (communication, marketing, public diplomacy, etc.) [6]. It is impossible to study the state as a brand without defining national identity.

A well-developed strong sense of national identity has the power to be a productive and enabling force within the society, providing positive social capital, with benefits such as improved cooperation with others, improved information flows, and more effective, better functioning government and other democratic institutions. National identity is the sense of belonging one has to a state or a nation, or a sense of solidarity one feels towards a particular group, disregarding one's actual citizenship status. If one views national identity positively, it is typically called "patriotism" [7, p. 77].

Patriotism presupposes pride for material and spiritual achievements of people, motherland, and a desire to save its characteristic features, its cultural acquisition, and protection of interests of the society, the nation as a whole. The associative images of these feelings can be colors, illustrations, signs, symbols, sounds, smells, which in some way are connected with the identification of a certain nation, people [8].

Patriotism, as a mental quality of human consciousness, is a kind of abstract unit that a person uses to reflect the experience of generations. The Philosophical Encyclopedic Dictionary defines this phenomenon as follows: patriotism (from the Greek "patria" - 
"motherland") is a love for the native land, responsibility for its fate, and willingness to serve its interests; in case of need, selfless defense of the achievements of its people; sociopolitical and moral principle, which in a general form expresses the above-mentioned feelings and emotional states in general [9, p. 471].

Patriotism is based on the emotional aspect of the nation-state outlook. Formed under the influence of traditions, life experience, value system, feelings, etc., patriotism creates prerequisites for a person's attitude to his compatriots, country, and the whole world. That is why it is important to realize that patriotism manifests a wide range of meanings, such as love, traditions, and beliefs.

The lexical and semantic feature of these linguistic units in the English-language newspaper discourse manifests itself in the heterogeneity of their meanings. Thematic indicators of belonging to different categories are the basis for the classification of the elements of the phenomenon. Any language means expresses the main indicator of the meaning of the notion: a lexical item, a phrase, a context:

1) Beliefs:

- formed by the tradition of positive perception: To defend my country was once called patriotism [10, Jan 26, 2019]. True love of your country means contributing fairly to build a decent society, as well as cherishing values of fairness, freedom, decency, and tolerance [11, Jun 25, 2017]. There is nothing wrong with patriotism - nationalism is maybe another matter - but I'm proud of my country and there is no shame in that [11, Nov 1, 2016]. I believe patriotism is a normal and healthy thing and the very opposite of nationalism [12, Apr 26, 2004];

- formed by the tradition of negative perception: President Donald Trump will preside over July Fourth Independence Day celebrations on Thursday with a speech about patriotism and a show of military might that critics say is politicizing an important holiday and wasting taxpayer money [10, Jul 4, 2019];

- a person's cognitive process: "Patriotism is something that I think" [12, Jan 13, 2019], "I do love Scotland, but if the love for your country is all you have, you're in a desperate state," he said, adding that he hated anti-English sentiment [13, Apr 13, 2018];

- a belief imposed by society: True love of your country means contributing fairly to build a decent society, as well as cherishing values of fairness, freedom, decency, and tolerance [13, Jun 25, 2017]. Patriotism requires you to put your country's needs before your personal wishes, so the country wins [13, Jan 18, 2019]. Was motivated by a sense of patriotism inspired by Independence Day [10, Jun 5, 2018];

2) Love: Patriotism is the love of one's country [12, Mar 31, 2007]. Patriotism, one is meant to feel, is an unrequited love [12, Jul 01, 2019]. Patriotism, according to the Oxford English Dictionary, which must surely be considered the right authority on this matter, is the quality of 'love or devotion to one's country' [13, Sep 7, 2017].

3) Traditions:

- self-fulfillment: The England skipper said: "The patriotism we have in our country I don't see anywhere else. At times like this, you will never see anyone like the English in the world" [14, Jan 13, 2004]. Australians have always gone to great lengths to profess their love for the sunburnt country - with many inking their patriotism to their bodies. But beyond the standard South Cross tattoo - or even an Aussie flag - some are expressing the patriotism in a rather more elaborate fashion [10, Jan 26, 2019]. European is who we are and who we have always been. Our members are Remain. Our values are Remain. Our hearts are Remain [11, Jun 18, 2019]. There is nothing wrong with patriotism ... I'm proud of my country and there is no shame in that [14, Nov 1, 2016];

- symbolism (flag, outfit): MAGA apparel as a symbol of patriotism [10, March 1, 2019]. His patriotism is evident in his new home, where a painted American flag hangs on the wall [10, Jan 24, 2019]. Both are dressed down in a casual style for the weekend, with Hoda - who reported on the 2016 Olympics for NBC - showing her patriotism in a Team $\underline{\text { USA jacket }}[10$, Oct 12, 2018]. Knowing all the words to your national anthem: flying a flag above your home, You'd argue or fight with someone who insulted your country, 
Watching the Queen's Speech every Christmas, Only buying products or food from your own country, Wearing clothes with your flag on them, Being able to name all the Royals, Having your country's flag on your car license plate, Knowing the Queen's birthday, Having your country's flag on your car [13, Apr 19, 2018]. The bald eagle, designated as the national emblem of the United States in 1782, has long symbolized the American ideal of freedom. For people like Kevin Fossett, a U.S. Navy veteran who likes to check up on a nest in Florida, the sight of the birds stirs feelings of patriotism, especially with the approach of Independence Day [10, July 3, 2019]. The rule of raising of the national flag is to strengthen national consciousness, help religious believers better practice socialist core values and carry forward the tradition of patriotism [10, Aug 3, 2018];

- pride: the London Olympics will provide a boost in patriotism and pride [14, Nov 22, 2011].

The inner content of patriotism is the signs - the results of the process of understanding the essence of a certain social phenomenon, presented in the newspaper discourse. A characteristic feature of contemporary media is the search for new, striking means: words, images, and stylistic techniques. To enhance the expressiveness and emotionality of the language, to more accurately translate the content and express a generalized meaning, to create an appreciable effect in the language of the media, various stylistic tropes are used. A significant body of examples that illustrate the phenomenon of patriotism in the Englishlanguage newspaper discourse is represented by such stylistic means as metaphor, epithet, and comparison.

Metaphor as a phenomenon of consciousness is manifested in language, as well as in thinking and in action: "Our everyday conceptual system, within which we think and act, is essentially metaphorical" $[15$, p. 256]. For the most part, this stylistic tool is used to tune the addressee's behavior to an emotional level, which organizes and structures the human perception of the surrounding world [16, p. 53]. In the English-language newspaper discourse, metaphors have been found to fill the notion of "patriotism" with the following characteristics:

- a way to cause a negative reaction of the reader - lexical units that give the notion of patriotism a pejorative connotation: in tumult of patriotism [12, Apr 21, 2003]; a strong dose of patriotism [10, May 28, 2019]; patriotism suddenly looking phoney [11, Jan 22, 2019]; show of patriotism [10, Jun 30, 2016]; is fashionable to deride patriotism [10, Jun 30, 2007]; patriotism - it's the last refuge of a scoundrel according [10, Jun 19, 2016]; patriotism and pageantry [12, March 5, 2019]; orgy of patriotism [10, Jun 10 2006]. Of all the moral and intellectual nonsenses available to us, patriotism is among the dumbest. To be proud of others' achievements is the same as standing in your living room, awarding yourself a medal for the performance of Paula Radcliffe at the marathon [12, Mar 31, 2007]. We're going to do everything short of what's downright criminal. Ethics don't matter. Patriotism doesn't matter [13, May 11, 2019]. Patriotism is love of one's country, but are countries really appropriate objects of love? [12, Mar 31, 2007]; crack of patriotism [10, May 17, 2003]; patriot games [12, May 21, 2009];

- manipulative use of patriotism: capitalize on Olympics patriotism [12, Aug 20, 2012]; can't hide behind patriotism [12, Aug 14, 2017]; in tumult of patriotism [12, $21 \mathrm{Apr}$, 2003]; grief and a mist of defiant patriotism [12, Jul 01, 2019]; lure of false patriotism [12, Mar 28, 2014]. IT appears to be obligatory for analysts on CBS and Fox to wear American flag pins on their lapels during coverage of NFL games. Pundits' patriotism is complete overkill [13, Jan 18, 2012];

- a way to arouse a positive reader reaction - lexical units that give the notion of patriotism a positive and solemn connotation: a wave of patriotism [13, Mach 8, 2019]; to stoke patriotism [10, Aug 15, 2018]; the dance was "a display of patriotism" [10, Oct 4, 2013]; the heinous crimes against patriotism [10, Jun 22, 2009]. The battle that ensued as a fight for nothing less than civilization itself that was won by Allied forces who were driven_by spirit, patriotism and military might [10, Jun 6, 2019]; patriotic sentiment [14, Oct 8, 2018]; responding to the anger with a measure of patriotism [14, Oct 2, 2018]; 
patriotism is back in intellectual fashion [12, Dec 27, 2005]; patriotism is back [12, Jan 25, 2011]; a bit of patriotism could make us all happier [12, Apr 22, 2012]; forward to sharing their patriotism [13, Nov 30, 2015].

Epithets being the most popular linguistic means vividly representing the phenomenon of patriotism reveals the author's vision of the world picture. The epithet helps to give a clearer assessment of a certain fact, to sharpen the reader's attention, characterizing the object from the point of view of the author's perception, necessarily contains a subjective assessment of the relevant fact [17, p. 127]. In the English-language newspaper discourse, epithets were found to fill the notion of patriotism with the following characteristics:

- sensitivity: heart-felt patriotism [8, Jun 20, 2018]; compassionate outwardlooking patriotism [12, May 13, 2019]; defiant patriotism [12, Sep 12, 2002]; quiet patriotism [12, Apr 01, 2003]; cultural patriotism [12, Nov 19, 2001]; wounded patriotism [12, Feb 10, 2017];

- prudence: not blind patriotism [12, Jan 7, 2014];

- effectiveness: embattled patriotism [10, Jun 22, 2014];

- condemnation: phoney patriotism [13, Jun 25, 2017]; vacuous patriotism [13, Jan 22, 2019];

- mockery: feigned patriotism [10, Mar 18, 2018], patriotism is not arrogant, or overbearing [10,, Jul 6, 2018];

- disrespect: plastic patriotism [13, Apr 13, 2018];

- disgust: foul patriotism [13, Aug 9, 2012];

- scale: radical patriotism [9, May 3, 2019]; party's patriotism [12, Oct 09, 2003]; local patriotism [12, Mar 18, 2004];

- territoriality: France's economic patriotism [12, Aug 30, 2005]; British patriotism [14, Mar 12, 2019]; Chinese patriotism [11, Sep 4, 2012]; Welsh patriotism [9, Mar 25, 2019]; German patriotism [10, Mar 20, 2001]; English patriotism [12, Apr 22, 2012]; Russian patriotism [12, Aug 27, 2005]; Italian patriotism [12, Dec 7, 2016];

- manipulability: forced patriotism [13, Aug 4, 2013];

- positivity: good honest patriotism [10, Mar 24, 2005]; cultural patriotism [12, Nov 19, 2001].

Comparison gives the expression particular clarity, expressiveness, and associativity [18, p. 200]: Tory Cabinet Minister Andrea Leadsom's patriotism is all the hypocrisy of a well-heeled banker waving a cheap plastic Union Jack made in China [11, Jun 25, 2017]; patriotism ambiguous and conveniently pliable tool [11, Sep 7, 2017]; American patriotism is a revelation [12, Jul 2, 2015]. The introduction of this stylistic tool helps the author create a clearer reader's idea of the events described in the text [19, p. 8].

Conclusions. Thus, the usage of the phenomenon of patriotism in the newspaper discourse is contributing to the formation of the country's national brand. Each newspaper text contains certain linguistic and pragmatic parameters of this notion that have a significant impact on its semantic structure. Newspaper texts are designed to attract the attention of the readership and arouse interest in the issues of national identity. This is a part of the process of national branding by means of the newspaper language. While pursuing the goal of informing the public about the situations with patriotism, journalists often resort to expressive means to emphasize the meaning of words and influence readers' perceptions. Thus, the linguistic and pragmatic aspects of the phenomenon of patriotism in the language of contemporary English-language media fulfill certain functions. They are informative (influence on the intellectual sphere), evaluative (influence on the system of views, change of attitude of the addressee of the message to the phenomenon), and instructive (influencing the behavior of the recipient of information using lexical and grammatical and stylistic linguistic means). We see the prospects for further research in considering the multimodal nature of national branding and the phenomenon of patriotism as its integral part. 


\section{СПИСОК ВИКОРИСТАНИХ ДЖЕРЕЛ}

1. Фоменко О.С. Національний брендинг як явище сучасного комунікативного простору (на матеріалі англійської мови) // Мова і культура. (Науковий журнал). К.: Видавничий дім Дмитра Бураго, 2009. - Вип. 12. - Т. Х (135). - С. 80-88.

2. Фоменко О.С. Королівське весілля як стратегія корекції іміджу британської монархії (на матеріалі англійської мови) / Фоменко Олена Степанівна // Мовні і концептуальні картини світу: зб. наук. праць. - К.: Видав. Дім Дмитра Бураго, 2011. - Вип. 37. - С. 392-399.

3. Радзієвська Т. В. Комунікативно-прагматичні аспекти текстотворення: автореф. дис.. канд. філол. наук. - К.: Інститут української мови НАН України, 1999. - 33 c.

4. Козловець М. А. Національна ідентичність у контексті глобалізації: соціальноілософський аналіз : автореф. дис ... д-ра філос. наук : спец. 09.00.03 / М.А. Козловець. - К., 2010. - 36 с.

5. Wodak Ruth, de Cillia Rudolf, Reisigl Martin, Liebhart Karin (Eds.) The Discursive Construction of National Identity / Ruth Wodak, Rudolf de Cillia, Martin Reisigl, Karin Liebhart Edinburgh: EUP, 1999. - 276 c.

6. Ejov C. National branding: theoretical, methodological and practical aspects (case study of latvia, estonia and Republic of moldova) / Christina Ejov, Alexandr Ejov // Eastern Europe-Regional Studies [Electronic resource]. - Access mode : http://psage.tsu.ge/index.php/Easternstudies/article/view/117

7. Imran S. Strengthening the National Identity through Brands / Sana Imran // Advances in Economics and Business, 2017. - 5(2). - C. 76-82

8. Bozhkova V. V. Usage of patriotic motives in promotion of products in markets / V. V. Bozhkova, O. V. Prokopenko, M. O. Prokopenko // Economic Processes Management: International Scientific E-Journal, 2015. - № 4. [Electronic resource]. - Access mode : http://epm.fem.sumdu.edu.ua/download/2015_4/2015_4_9.pdf

9. Філософський енциклопедичний словник / В І. Шинкарук та ін. К.: Інститут філософії ім. Григорія Сковороди НАНУ, 2002. - 742 с.

10.Daily Mail Online [Electronic resource]. - Access mode : https://www.dailymail.co.uk/home/index.html

11. Sunday Express [Electronic resource]. - Access mode : http://sundayexpress.co.ls/

12. The Telegraph [Electronic resource]. - Access mode : https://www.telegraph.co.uk/

13. Mirror [Electronic resource]. - Access mode: https://www.mirror.co.uk/

14. Morning Star [Electronic resource]. - Access mode : https://www.morningstar.com/

15. Lakoff G. Metaphors We Live By. Chicago : Chicago University Press, 1985. $-242 \mathrm{c}$.

16. Fauconnier G. Rethinking metaphor. The Cambridge Handbook of Metaphor and Thought / edited by R. W. Gibbs. NY : Cambridge University Press, 2008. - C. 53-67

17. Онопрієнко Т. М. Епітет як первісний троп і системоутворюючий центр тропів. Вісник ЖДПУ. Житомир : Вид-во ЖДУ ім. І. Франка, 2001. - № 8. - С.127-130.

18. Прунч Эрих. Пути развития западного переводоведения. От языковой асимметрии к политической. / Пер. с нем. - М.: Р. Валент, 2015. - 512 с.

19. Овсянко О. Л. Структурно-семантичні модифікації англомовних прислів”ї у художньому та публіцистичному дискурсах : автореф. дис ... канд. філол. наук : 10.02.04. Запоріжжя, 2017. - 20 c.

\section{REFERENCES}

1. Fomenko O. S. (2009) Natsional'nyy brendynh yak yavyshche suchasnoho komunikatyvnoho prostoru (na materiali anhliys'koyi movy) [National branding as a phenomenon of modern communicative space (in English)] // Mova i kul'tura. (Naukovyy zhurnal). K.: Vydavnychyy dim Dmytra Buraho, Vyp. 12. T. X (135).

2. Fomenko O.S. (2011) Korolivs'ke vesillya yak stratehiya korektsiyi imidzhu brytans'koyi monarkhiyi (na materiali anhliys'koyi movy) [The Royal Wedding as a 
Strategy for Correcting the Image of the British Monarchy (in English)] / Fomenko Olena Stepanivna // Movni i kontseptual'ni kartyny svitu : zb. nauk. prats'. Kyiv. Vydav. Dim Dmytra Buraho. Vyp. 37.

3. Radziyevs'ka T. V. (1999) Komunikatyvno-prahmatychni aspekty tekstotvorennya: avtoref. dys.. kand. filol. nauk. [Communicative and pragmatic aspects of text-making: abstract of the thesis for the $\mathrm{PhD}$ of philolological sciences]. Kyiv: Instytut ukrayins'koyi movy NAN Ukrayiny.

4. Kozlovets' M. A. (2010) Natsional'na identychnist' u konteksti hlobalizatsiyi: sotsial'noilosofs'kyy analiz : avtoref. dys ... d-ra filos. nauk: spets. 09.00.03 [National identity in the context of globalization: socio-philosophical analysis: abstract of the thesis for a Doctoral degree of Philosophy: Speciality: 09.00.03] / M.A. Kozlovets'. Kyiv.

5. Wodak Ruth, de Cillia Rudolf, Reisigl Martin, Liebhart Karin (Eds.) (1999) The Discursive Construction of National Identity [Текст] / Ruth Wodak, Rudolf de Cillia, Martin Reisigl, Karin Liebhart Edinburgh: EUP.

6. Ejov C. National branding: theoretical, methodological and practical aspects (case study of latvia, estonia and Republic of moldova) / Christina Ejov, Alexandr Ejov // Eastern Europe-Regional Studies [Electronic resource]. - Access mode : http://psage.tsu.ge/index.php/Easternstudies/article/view/117

7. Imran S. (2017) Strengthening the National Identity through Brands / Sana Imran // Advances in Economics and Business, 5(2).

8. Bozhkova V. V. Usage of patriotic motives in promotion of products in markets / V. V. Bozhkova, O. V. Prokopenko, M. O. Prokopenko // Economic Processes Management: International Scientific E-Journal, 2015. - № 4. [Electronic resource]. - Access mode : http://epm.fem.sumdu.edu.ua/download/2015_4/2015_4_9.pdf

9. Filosofs'kyy entsyklopedychnyy slovnyk [Encyclopedic Dictionary of Philosophy] (2002) / V I. Shynkaruk ta in. K.: Instytut filosofiyi im. Hryhoriya Skovorody NANU.

10. Daily Mail Online [Electronic resource]. - Access mode : https://www.dailymail.co.uk/home/index.html

11. Sunday Express [Electronic resource]. - Access mode : http://sundayexpress.co.ls/

12. The Telegraph [Electronic resource]. - Access mode : https://www.telegraph.co.uk/

13. Mirror [Electronic resource]. - Access mode: https://www.mirror.co.uk/

14. Morning Star [Electronic resource]. - Access mode : https://www.morningstar.com/

15. Lakoff G. (1985) Metaphors We Live By. Chicago : Chicago University Press.

16. Fauconnier G. (2008) Rethinking metaphor. The Cambridge Handbook of Metaphor and Thought / edited by R. W. Gibbs. NY : Cambridge University Press.

17. Onopriyenko T. M. (2001) Epitet yak pervisnyy trop i systemoutvoryuyuchyy tsentr tropiv [Epithet as the primitive trope and system-forming center of the tropes.]. Visnyk ZHDPU. Zhytomyr: Vyd-vo ZHDU im. I. Franka.

18. Prunch Erikh (2015) Puti razvitiya zapadnogo perevodovedeniya. Ot yazykovoy asimmetrii k politicheskoy [Ways of development of Western translation studies. From linguistic asymmetry to political]. / Per. s nem. M.: R.Valent.

19. Ovsyanko O. L. (2017) Strukturno-semantychni modyfikatsiyi anhlomovnykh prysliv"yiv u khudozhn'omu ta publitsystychnomu dyskursakh : avtoref. dys ... kand. filol. nauk: 10.02.04 [Structural-semantic modifications of English proverbs in artistic and journalistic discourses: abstract. dissertation ... Cand. philol. Sciences: 10.02.04. [Abstract of the thesis for the $\mathrm{PhD}$ of philolological sciences 10.02.04.]. Zaporizhzhya.

Received: 26 April, 2020 